\title{
Students' Perceptions of M-Learning Activities within the Algerian Context
}

\author{
Dr Imane Tiahi \\ The University of Northampton \\ Waterside Campus \\ UK
}

\begin{abstract}
This study aimed to explore student engagement and interaction with m-learning activities in EFL(English as a Foreign Language) within the Algerian context at Teaching Training Institute. Three mobile applications were used to achieve the aim; these are Padlet, Kahoot, and Sli.do. This research project is a qualitative case study that engages 10 undergraduate students (18-20 years) who took part in eight sessions (two sessions held in each week). The findings were collected through reflective journals. The findings have fundamental implications for EFL teachers and institutional leaders who aim to provide an opportunity for students to engage with the English context through $\mathrm{m}^{-}$ learning. The results were thematically analysed. It was evident that students provided positive attitudes towards $m$ learning activities. It is not only motivating but also engaging in learning processes; the m-learning apps were well received, and thus research can be taken further to examine their possible impact within the Algerian context.
\end{abstract}

Keywords: student engagement and interaction; m-Learningactivities; English language learning, Algerian context, mobile applications; student perceptions; qualitative case study.

\section{Introduction}

English is the third foreign language that is formally taught in the Algerian educational system from middle school up to university level. The English curriculum is based on four language skills; reading, writing, listening and speaking. However, EFL teachers at university level find themselves facing students who pass exams but have few skills in dealing with the language communicatively and collaboratively. Ghomari (2015) argued that teaching English in the Algerian university faces some difficulties in guarantying the attainment of communicative competence in English for its students. This deficiency is the natural outcome of traditional non-native classroom environment that suffers an acute lack of interpersonal interactions in the target language and no exposure to authentic environments, which are two basic elements in the acquisition of a foreign language. This has been justified by Benmoussat and Benmoussat (2018) who argued that the teach-to-the-test is acknowledged to impact the teaching/learning process negatively, consequently, calls into question the credibility of the educational system as a whole. According to social constructivist, learning takes place through language and dialogue between two or more learners (Pritchard and Woollard, 2010). Thus, this research aims to explore how m-learning enhances student engagement and interaction via m-learning activities and research to discover the perceptions of students towards the latter is equally important.

\section{Review of the literature}

In the constructivist classroom, the learners are the makers of meaning and knowledge through interaction. Building a classroom where interaction is prominent helps develop effective classrooms. Students have a lot to offer one another. When students master completion of projects or activities in a group, the internalisation of knowledge occurs for each individual at a different rate according to their own experience. Vygotsky (1968) believed that internalisation occurs more effectively when there are social interaction and engagement. According to Appleton et al. (2006), engagement reflects a person's active involvement in a task or activity. In the same vein, Xerri et al. (2018) argued that student engagement in academic activities is a critical factor contributing to the overall success of students studying in higher education institutions. Yet the factors influencing student engagement in academic activities are still largely unknown. Xerri's et al. (2018) study suggests that student-student (peer) relationships, teacher-student relationships, and a students' sense of purpose for studying a higher education degree, were central to student engagement in academic activities. To this end, this research aims to facilitate student-student and teacher-student interaction via Kahoot, Padlet, and Sli.do.

The literature reviews the positive trends about Kahoot, Padlet, and Sli.do mobile applications on students' learning such as: providing immediate feedback, increasing participation and engagement (Hunsu et al., 2016). 
Based on these assumptions, it is worth exploring these m-learning activities as a means to explore to what extent these assumptions can be applied in the Algerian context. According to Sera and Wheeler (2017) and Fuchs (2014), these mobile applications may enhance students' social learning by introducing class discussion and presenting them with visual media and provide a non-threatening space for sharing and collaborating in classroom activities. The anonymity associated with the online platforms gives equality of status and can overcome social structures of the open classroom and the difficulties that classrooms can sometimes present for individuals. Those difficulties might mean some individuals contribute poorly or do not contribute at all. Pritchard and Woollard (2010) stated that the relationship between individual learners and the teacher is enriched through this extra dimension to their communication; this can lead to more positive relationships. In doing so, I have applied an intervention course that aimed at encouraging student engagement with the m-learning activities via different platforms such as; Sli-do, Kahoot, and Padlet. Thus, the current research gathered the students' reflection on the learning materials as a way of encouraging student engagement.

Regarding the mentioned literature review above, the following research question was answered in the present study:

RQ: How do students perceive the use of m-learning activities in the classroom to enhance engagement and interaction?

\section{Methodology}

\section{A qualitative case study}

Baxter and Jack (2008) argued that the qualitative case study methodology provides tools for researchers to study complex phenomena within its context. The purpose of this qualitative case study was to explore better students' perceptions of m-learning activities to enhance their engagement and interaction. The research design derived from the research question to understand students' learning process. The case study is an appropriate strategy for answering questions about how (Creswell, 2014). For this study, the case was the Teaching Training Institute, the context was the classroom, and students were the units of analysis.

\section{Participants}

To carry out this research, 10 Algerian EFL students from Teacher Training Institute were recruited voluntarily. The student volunteers are themselves going to be teachers; therefore, it is hoped they will find their interest in this research project which will help them for professional development and assist them in their future career as teachers. Thus, fruitful results derived in accord with enthusiastic interest and passion.

\section{Instrument}

I have created a range of m-learning activities via Padlet, Kahoot, and Sli.do over four weeks to ensure engagement of all students. The learning skills I am focusing on in this research project covering academic speaking, academic writing, academic listening, and academic reading. The tasks are divided into pre-session, in-session and post-session (see table below as a sample).

\begin{tabular}{|c|c|}
\hline Title & Presentation skills \\
\hline Study time & Two-hour seminar \\
\hline Purpose & Practice presentation skills \\
\hline Task & $\begin{array}{l}\text { Pre-session: How to speak so that people want to listen? Listen to the talk } \\
\text { https://www.ted.com/talks/julian_treasure_how_to_speak_so_that_people_want_to_listen/up-next and } \\
\text { post your notes on Padlet. } \\
\text { In-session:Designing the questions to explore student understanding in the form of a quiz via Kahoot } \\
\text { and Sli.do, asking students to watch short audios about speaking in a foreign language and how to } \\
\text { practice speaking and post their notes on Padlet and give comments to one another. } \\
\text { Post-session: Select an inspiring, discipline-related TED TALK from the website } \\
\text { https://www.ted.com/talks, summarise (up to } 100 \text { words), and paste the title, link to the listening, and } \\
\text { summary on Padlet. }\end{array}$ \\
\hline $\begin{array}{l}\text { Reflection and } \\
\text { feedback }\end{array}$ & $\begin{array}{l}\text { To gain more understanding of their attitudes toward the methods of academic speaking } \\
\text { Access the Padlet and Kahoot }\end{array}$ \\
\hline
\end{tabular}

Table 1m-learning activities 


\section{Data collection procedure}

According to Dyment and O'Conell (2003), journal reflection helps the individuals to reflect upon their reactions to the actions, self-assessment and collaborative evaluation. Reflective journals help the learner to deliberately think about past or impending actions, intending to affect future improvement (Hatton and Smith, 1995). Phelps (2005) maintains that the journals not only are an essential means for the collection of data in qualitative research about the student teachers but also enable "us" - teacher educators who research their work - to learn about ourselves. In her opinion, the data of the journals provide significant insights not always achieved through other ways of data collection. The advantages of the use of reflective journals are to improve the learning of student teachers and instructors, as well as improving the learning processes (Dyment and O'Connell, 2011). Writing in a personal reflective journal may be valuable to student teachers for developing meta-cognitive abilities and for promoting their self-orientation and responsibility for the processes of their personal and collaborative learning. Reflection can also serve as a guide for future action; each of the activities in the intervention course was designed to have an element of reflection. The effectiveness of reflective journals, as explained above, can be seen in line with my research, considering the perceptions ofstudents towards m-learning activities in the classroom. As such, when students were reflecting on the goal of classroom activities - the data collected from this mode had assisted me as a researcher to evaluate their attitude, readiness, perception and various facets which in a bigger picture help to justify the conclusion of this particular study.

\section{Data analysis}

For the analysis of reflective journals, thematic analysis was applied. Thematic analysis is an exploratory approach where analysts code or mark their sections of a text according to their patterns contributing to some relevant themes, Braun and Clarke (2006, p.79) define it as "... a method for identifying, analysing and reporting (themes) within data". Thematic analysis is frequently employed in qualitative research because themes and patterns of significant interest across data set that play a vital role in describing phenomena under investigation (Braun and Clarke, 2006). Thematic analysis involves six steps which will be explained below: familiarisation with the data analysis, coding procedure, searching for themes, defining and naming themes, producing the report. In my research, I had coded participants' reflective journals to ensure rich data will be collected. After coding, I generated themes and divided them into chunks.

\section{Ethics considerations}

This exploration utilized some ethics rules for maintaining integrity - for instance, consent forms, participant information sheets, privacy, and data storage. As stated by O'Leary $(2010$, p.41), the guidelines for research ethics generally include "ensuring respondents have given informed consent...ensuring no harm comes to respondents'...ensuring confidentiality and, if appropriate, anonymity." I adhered to the University of Northampton ethical guidelines for conducting my project. Any personal details were stored separately to research data to ensure the anonymity of the subjects is protected in the event of any security issues. This data storage complied with the Data Protection Act (1998).

\section{Results}

This section considers participants' reflection of how the potential of the m-learning apps appears to have enhanced their engagement in the classroom. Participants also stated that the idea of reflection allowed them to self-reflect upon their learning using various mobile applications Sli.do, Kahoot, and Padlet.

They noted that they could improve their discussions and questioning skills in comfortable platforms.

\begin{tabular}{|l|l|}
\hline Themes & Codes \\
\hline Theme 1: m-learning & Definitions \\
\hline Theme 2:m-engagement & Collaboration and interaction \\
\hline Theme 3: student input & Active learning \\
\hline Theme 4: characteristics of m-learning & $\begin{array}{l}\text { Anonymous participation, self-confidence, the } \\
\text { immediacy of responses, flexible learning, variety in } \\
\text { teaching }\end{array}$ \\
\hline $\begin{array}{l}\text { Theme 5: teachers' roles from students' } \\
\text { perspectives }\end{array}$ & Guide, facilitator \\
\hline $\begin{array}{l}\text { Theme 6: the future of m-learning within the } \\
\text { Algerian context }\end{array}$ & Positive \\
\hline Theme 7: challenges & Wi-Fi connection, distraction \\
\hline
\end{tabular}




\section{Theme 1: m-learning}

Table 2 Themes and codes

Student participants provided some useful definitions of m-learning:

Cilia defined mobile learning as:

Acquiring knowledge through mobile applications, using the net (Cilia).

Hadjer added:

Mobile learning is concerned with having access to the Internet via mobile technology such as a cell phone. For me, mobile means moving. Information in the $21^{s t} C$ is accessed, transmitted and received through different means, which are moved from traditional prints to online copies via technology. Then, individuals interact with information through various means, such as smartphones and tablets (Hadjer).

Another participant (Ahmed) defined it as:

Mobile learning is when learners use their mobile devices to perform activities beyond simple communication. For example, doing some research, reading, note-taking, recording lectures. Or taking videos or pictures for presentation and conferences (Ahmed).

Fatima reported that:

Mobile learning is concerned with the use of devices, including smartphones, laptops, and personal computers, to get information (Fatima).

\section{Theme 2: m-engagement}

The key feature of these apps is that they allow students to create personalised learning by which they can collaborate. Students made presentations using Padlet app. As noted by students, they were able to move from a random use of their mobiles to an awareness of the different functions that mobile holds to enhance their engagement in the EFL classrooms.

Ahmed states positive reflection saying that:

It is my first time I am using these kinds of applications, and I confess that their integration in our course or EFL, in general, will give students the freedom to express their learning styles, their needs and their engagement with students and teachers as such (Ahmed).

Without forgetting the importance of developing the four skills necessary for learning English as writing, speaking, reading, and listening, these applications tend to help student engagement with the content. Cilia mentioned in her reflective journal:

Along with having fun, I personally found the sessions provided by the researcher very informative, engaging, I also learned the skills I require to thrive in my future ventures and university life (Cilia).

More conveniently, when you talk about m-learning, students can reflect anywhere. Mobile applications used in the intervention have helped the:

Ease of communication amongst my peers and also with my teacher (Houda).

Similarly, Leila also reflected that:

We can reflect on the content, activities, I can post in my spare time, it is like learning can happen anywhere and anyplace (Leila)

Recalling was also another element that students mentioned in their reflections. This was shared by most of the participants; one said that:

The advantages of these apps help students to recall. This may help us in our examination too as I always can refer to (Mustafa).

The participants also acknowledged the importance of discussions and sharing knowledge. Mohamed clarified this point:

When I went to revise other students' reflection in Padlet, it is impressive to see another students' perspective in one go (Mohamed).

Soumia was also optimistic about mobile applications used in the intervention course; she clearly stated that:

It helps me widen my knowledge and my critical thinking when I read other students' point of view (Soumia). 
Thus, the concepts of anywhere/anytime, teamwork, collaboration, discussions and engagement repeatedly mentioned by all the participants who gave a promising future for m-leaning in HEI's in Algeria.

These findings further support the idea of knowledge sharing. Students reported that the mobile apps provided them with alternative views from different individuals on a topic. This concept of 'sharing' was also recurrent by many participants who clearly shows the importance of socially constructing their knowledge and critical thinking with their classmates.

The use of Padlet and Sli.do specifically seemed to create optimal conditions for students to interact with their classmates socially.

We were able to ask questions as well as interact with my classmates. Also working as a group strengthens bonding and enthusiasm among class environment (Leila).

Additionally, the use of the chosen apps facilitates the interaction with the teacher as well. Many students expressed their need and importance of communication between the teachers and fellow students for developing their English skills as well as their communication. One of the students stated that:

Being able to share and communicate with my classmates was so useful and effective (Imene).

Concerning the engagement of students which is one main focus of this research, students preferred working together as this allowed them to work in teams and develop their interaction with one another. Mohamed noted that:

I like this method of teaching which is based on collaborative tasks because simply it helped me create a good bond with my classmate and also increased my confidence to speak in the classroom. I was not able to know all the class because I had never been introduced to them. I always felt shy to share my thoughts with my classmates. I will consider this in my future career as a teacher and try to use these apps in my class hopefully (Mohamed).

One unanticipated finding was that students develop their self-development and self-directed learning.

We started by sharing our thoughts on Padlet and post our question on Sli.do; then we got the opportunity to work in groups to discuss further what has been posted. We also commented on each other's work; it was both informative and funny to see some jokes about other students' feedback. Also, the advantages of these apps keep all the names were anonymous, which also gave us the freedom to post (Cilia).

Furthermore, students' contributions in giving feedback to one another was another advantage noted by students. This allows them to notice their errors and to contribute collaboratively for good results.

Working collaboratively contributed to the enhancement of our communicative and productive skills (Soumia).

They liked the idea of competition through the game, which also added the element of curiosity and enthusiasm.

I am so excited about the idea of doing activities in the form of a competitive game. This makes me and my colleagues more enthusiastic and curious to learn more (Houda).

They informed that various games which formed the part of Kahoot application were engaging and interactive.

Playing interactive games inside the classroom, using mobile applications, specifically Kahoot, is very important for me as a student to engage in the class discussions. I believe it is effective warming up method (Leila).

Thus, students positively acknowledge the benefits of the three apps used in this study as a new learning approach.

\section{Theme 3: Student input}

Effective learning happens when students can provide inputs in what ways they prefer to learn. The majority of students raised negative points about the current curriculum. They felt that it is more exam-oriented and does not meet students' needs. It is focusing on one skill (grammar, phonetics, basic writing skills) instead of taking account other skills like effective communication and class interaction. This was widely believed, and one student pointed out that:

Teaching grammar can be important, but the shift should occur to enhance other skills as such. We are taught just to prepare for the exams and pass, and this can be considered as a negative point (Ahmed).

Students were able to reflect their thoughts about the content included in the intervention, which according to them, is missing in their current curriculum. One student stated that:

The traditional approach of teaching in Algeria dominated the education sector, where students' voice is limited (Fatima).

It has even been mentioned that the curriculum is not suitable for university students who are going to be future English teachers. For instance, in oral expression, some topics are not relatively for university level. One student suggested that: 
The topics should include how to effectively build confidence, activities that should link to our future career perhaps. Not only focusing on grammar and phonetics (Fatima).

Some of the topics are not culturally matching the country's culture. For instance, topics like snow white will not enhance students' interaction because they may not have much knowledge about it. One student said:

Sometimes I cannot participate because of a lack of knowledge. The curriculum should integrate culturally-oriented topics. This is another reason not to be motivated (Cilia).

\section{Theme 4: characteristics of m-learning}

\section{Anonymous participation}

The apps chosen allowed students to be anonymised. This allows them to participate in the activities. Students identified some of the positive characteristics of these media in terms of the authenticity of the tasks which were linked to real life, learner-centred, reflective, and engaging. The students also reported that the application of these technological tools made the class enjoyable and prevent monotony. One student said:

I think that it's a good idea to share your knowledge through these applications (Houda).

\section{Self-confidence}

Although most students agreed that they do not have much experience in using their mobile for learning, but they were all happy to integrate it. One of the students said:

We can share our learning confidently, where my classmates can provide feedback during the task. We just need to share it on Padlet or Sli.do (Leila).

Secondly, collaboration seemed to have an impact on students' participation and engagement. Students often mentioned in their reflective journal that they felt motivated to finish their tasks.

Some students also showed some fear of the use of technology; however, this view changed when they get the chance to practice.

In the beginning, I was not confident to use my mobile in the classroom., I thought this approach will be challenging for me, but I found it enjoyable as well as informative (Mustafa).

With respect to studentengagement, most students felt confident in engaging, which led them to improve their speaking skills.

To be honest, I enjoyed your sessions, and I think teacher sat E.N.S should integrate interactive mobile apps so that we can share our thoughts and to develop our language skills needed for our future career (Mohamed).

In their interviews teachers mentioned that students fear the stage and fear committing mistakes. Therefore, shyness and fear of stage as described by teachers were the main barriers that students do not participate. One of the students commented that:

Personally, I felt this course gave me the courage to overcome my nervousness and shyness. Previously, when I try to sit with my teachers to speak, I always fear to make mistakes in front of them, which I do not know the reason. Although some teachers encourage us to come and meet them still, there is a gap (Soumia).

Most students reported that their engagement and enthusiasm towards learning a foreign language has changed.

Padlet app has provided me with the opportunity to think-share-pair with my classmates and increased my selfconfidence as well as my engagement (Hadjer).

\section{Immediacy of responses}

Using the three mobile apps during the mini-module (intervention course) gave a new dimension to the whole process of teaching through which students were able to receive instant feedback from their peers.

I liked the idea of posting the feedback to other classmates' work; it was constructive and enjoyable to learn and continue to become better at using the apps as well (Ahmed).

Another student said:

Giving and receiving feedback absolutely good way to improve my English. Also, projecting the feedback was also effective in terms of time usually the teacher spends to feedback everyone (Fatima).

\section{Flexible learning}

Flexible learning would not be possible without the affordances that the mobile apps create. 
I liked the simplicity of the apps used in this research. These apps make us engage and without them, the learning objectives will not be achievable. I also found that using mobile phones is much easier when it comes to flexibility. Since in our institution we have only two language laboratories which are mostly used by tutors who teach oral expression module, I feel that using our mobiles phones in classrooms will be a solution (Cilia).

One of the comments students made is that m-learning may help in developing a pedagogy that can match the old and new teaching methods. One stated that:

An opportunity to blend or reconcile the old and new ways of teaching and learning (Imene).

This can be explained as the use of technology should always be pedagogy driven, so it should be easy and effective if carefully planned and considered.

Students characterised m-learning as portable, they stated that:

Portability and interoperability may help students to exchange and construct knowledge. Teachers need to be engaged with and contribute to the "activity" that is generated, in order for students to persevere and make it sustainable (Houda).

Kahoot and Sli.do may increase motivation and attention through presentation styles, competition, and interaction. Students clearly enjoyed the sessions, one stating that:

I find Kahoot is excellent for,in-class participation, self-assessment of learning and gives me insight into what was generally understood by the class. Also, it creates a positive, fun atmosphere (Leila).

\section{Ali mentioned that:}

These apps ensure all learning is accessible to all, exciting, fresh, and making sure students build in social learning, so students become an advocate (Mustafa).

Another interesting reflection from Meriam is that:

These mobile apps make learning out loud (Mohamed).

Sara said:

Mobile learning develops productivity since learners are exposed to authentic materials, learn new vocabulary; hence, they become more engaged in classroom discussions (Soumia).

To sum up, Ahmed stated the positive side of applying mobile learning particularly in EFL:

- Easy and instant access to all kinds of useful information.

- Share files and documents easily.

- Recording lectures.

Variety in teaching

Using mobile applications in class adds variety to the teaching style, which made the learning interesting. For instance, Ali mentioned that using these mobile applications helps all students to engage:

By using Kahoot, Padlet, and Sli.do, teachers can tackle all the learning differences (Hadjer).

It was also noticed that students were interested in what was presented from the mini-course. Ahmed said:

I am very interested in using these technologies in the future. It did help my engagement skill, collaboration with others, and participation (Ahmed).

\section{Leila added:}

These technologies reinforce my learning. It is of big value to my achievement in the exam for instance (Leila).

Visual learning can be of paramount importance for students to be motivated. Students tend to engage more when the content contains some visual materials. One student reported that:

Much longer effect can be noticed when the teacher uses visuals in his/her teaching, we learn quickly and effectively if these apps are used by our teachers. Furthermore, these apps may give more opportunities for students to voice their thoughts in a constructive way (Houda).

The majority of students agreed that the use of technology can increase their attention and curiosity towards learning. Students reported that it is the responsibility of teachers to integrate technology into their teaching to make the class environment more interactive. One student mentioned that:

Although there are some limitations in Algeria about the availability of the Wi-Fi, I believe that every student holds a phone equipped with a $3 G$. So, the teacher should take this into account that we are aware of its benefits (Mustafa). 
Mobile learning can be represented in the form of anywhere, anyplace learning, and Houda also highlights the positive side about the use of mobile learning, stating that:

The easy access to information, to cope learning and teaching to this modern world's innovations, it is considered as an attempt to convince the actual generation to use technology in learning rather of limiting its use to non-academic usage (Houda).

Hadjersummarised that mobile learning may benefit students in terms of:

1- quick access to information, to elaborate on the world's views through mobile access to the Internet.

2-It is also helpful to create collaborative groups through mobile apps.

3- It involves learners in an active interaction when the activity is well managed by teachers.

\section{Theme 5: Teachers' role fromstudents' perspective}

The majority of the students agreed that these apps cannot be used without the guidance of the teachers. The students clearly showed the appreciation of the explanation they received from the teachers. Leila stated that:

The teacher's instruction was useful and needed to guide us and to realise our mistakes (Leila).

One student also stated that:

I strongly agree that mobiles need to be used in learning however, with instructions and careful watch by the teacher (Fatima).

The teacher-mediator has to teach the use of tools to students. That is why it is important to also focus on teachers' development and digital literacy. Students reported that:

The activities we used showed a balance of all aspects of learning English as a foreign language, it enhances our oral, written, and listening skills (Cilia).

\section{Leila also said the same:}

I agree that mobile phones should be controlled in classroom learning, and they can be accessed only through activity, to avoid learners' distractions. I believe everything should be used with limits.

Another participant stated that:

I support the idea that mobile learning should be applied. However, instructors should carefully observe students and control their behaviours (Mustafa).

However, some students did not feel comfortable using these apps. One student mentioned that his phone is not compatible with these apps. Others said that:

My typing style is very slow, so I would prefer to take notes on a piece of paper (Mohamed).

Besides, one student stated that:

Teachers should act as facilitators - as such, they should support, trigger responses, weave responses together and open new threads, or maybe just summarising main points (Cilia).

\section{Theme 6: The future of m-learning within the Algerian context}

The future of m-learning in Algeria depends on the openness of teachers and institutional leaders to allow students to use their mobile devices as part of the learning process, and not to take it as disrespectful behaviour. Also, Internet and IT services should far more be developed in the Algerian educational institutions for mobile learning to be successful. Fatima said:

It is very promising as every student is interested in learning through mobile, I observed that most of the students check information when doing their activity, as in higher education, faculties are using the Internet for teaching and learning purposes. In Algeria, smartphones become a fashion and learning is always possible as students are active and selfrelying due to the lack of print resources (textbooks) in English. However, in my opinion, mobile learning strongly relies on the availability of Internet and if this latter was slow or cut off, then the learning process will have to take a different direction (Fatima).

Cilia argues that:

I think this phenomenon of mobile learning is a given because students are using their mobile devices in class whether it was forbidden or part of a teaching method, therefore, including mobile devices as a learning tool in the EFL classes or any class for that matter will make it official and organised (Cilia).

\section{Mohamed also said:}


In the future, I will use it to engage learners in meaning search, collaborative work and interaction. Mobile learning might enhance productivity and engagement by allowing students to participate in classroom activities easier and faster (Mohamed).

\section{Contrary to these views, Ahmed stated that:}

The future of mobile learning in Algeria is not promising, unlike other countries. Algeria is so far behind to the point where we do not even have laptops in the classrooms (Ahmed).

For most participants, they strongly agree that smartphones should be allowed in the classroom if the number of students is small and the classroom is contained. Therefore, the lecturer will be able to notice any non-academic activities that the students might perform during class.

\section{Ahmed argued that:}

I think mobile learning may enhance productivity to a great deal if it is appropriately used with careful instructions fitting the aim of the presented lesson. All skills can be enhanced through it as this depends on the aim of the activities learners are involved in, but receptive skills are more adequate as interaction is the basis for online learning.

\section{Houda stated that:}

It is a good way to engage learners in activities through apps, as it might engage slow and quiet learners to be more involved in the interaction. They can improve their speaking and listening skills in a great deal.

Students argued that they do engage with different mobile apps to enhance their vocabulary and pronunciation. Well, I download books and articles to read, applications that help me to improve my pronunciation. Besides, some very beneficial dictionaries. Furthermore, I put the language of my mobile service in English, so it helps me to acquire new vocabulary concerning the services I need (Mustafa).

Imene argued that:

I use mobile to check the dictionary, I usually find it easy to check the meaning of concepts when I don't have access to my laptop. I also use mobile when I am travelling by train or bus to read online and to open my emails.

\section{Theme 7: Challenges}

Hadjer mentioned about the challenges in integrating m-learning in the teaching process stating that:

1- The negative side is that mobile use is too distracting, I personally waste time when apps send notifications, and I intentionally quit my work to check unrelated activities on the phone.

2- For learners, m-learning can be an easy way which drifts them away to visit libraries.

3- In learning, m-learning can be used but it should not be the focus as we are still in need of physical interaction that is based on the creativity and the personal critical thinking, as relying on the existing thoughts can inhibit individuals' thinking.

\section{This has been explained more by Leila who stated that:}

The overuse of mobile may lead to neglect the source of knowledge which are "hard copy" books, learners may be so dependent to their mobiles refusing any other material that may be more beneficial to their learning, the teacher may lose his control upon his learners (Leilla).

Another interesting challenge is the fact that some teachers forbid the use of phones in the classroom, this has been stated by Fatima:

I don't face any challenges (as I use it at home the most not in the classroom) except that I may complain about teachers who have forbidden us from the mobile use in learning (Fatima).

Fatima also stated that:

In my experience of using mobile blogging, I lost the Internet in the classroom, and students had to complete the activity outside the class (Fatima).

Ahmed also stated that:

- Students using the device for personal and non-academic activities, for example, texting friends and family, playing games, using social media etc

- A high chance of being a distraction from the actual lecture. 


\section{Discussion and conclusion}

In this section, the main research question of the study is answered based on the results obtained in the result section. After collecting students' reflections, the researcher analysed the data in order to find out the students' perceptions of $\mathrm{m}$-learning activities on student engagement. The findings showed that enhancing student ' $\mathrm{m}$-engagement' is one of the essential features of effective learning. The findings obtained from reflective journals indicate that students can improve their engagement through peer-led discussions and group work. The results of this study are in line with Pritchard and Woollard (2010), who stated that encouraging discussion among students and involving them in interactive activities are important for their active learning. Besides, this study lends support to Gregen (2015) and Bruner and Watson (1983) who confirmed that these discussions between the teachers and students, students and students within the classroom, draw attention to the quality of teaching and learning in an environment where collaboration occurs. In the same vein, Winer and Ray (1994) argued that collaboration improves students' learning by working as a group or in pairs to solve a problem.

The results indicated that giving the EFL students the chance to ask questions may help their engagement in the class. This view has been supported by Kuh et al. (2007) who argued that there are different activities which may help the facilitator to encourage students' interaction such as reciprocal questioning where students can ask questions at the same time getting feedback. Dillon (2007, p. 135) argued that teacher questions can serve as explicit 'pedagogical devices' to enhance student engagement. This agrees with Graham (2015), who stated that Kahoot app helps students to share and ask questions. This has also been supported by Jones (2008), who stated that "students should share, rather than withhold, their insights..." (p.62). Dewitt et al. (2015) also agree that students could learn and generate new ideas using Padlet tool. Generally speaking, Kahoot, Padlet and Sli.do help in enhancing student knowledge construction through discussions. One student stated that:

I find Kahoot is excellent for,in-class participation, self-assessment of learning and gives me insight into what was generally understood by the class. Also, it creates a positive, fun atmosphere (Cilia).

Students argued that these activities are enjoyable, fun and interactive, which enabled them to better understand the lessons. One student said:

I liked the simplicity of the apps used in this research. These apps make us engage and without them, the learning objectives will not be achievable. I also found that using mobile phones is much easier when it comes to flexibility(Ahmed).

Although students said that technology is a great tool to engage the class in an effective way, it was also claimed that teachers' role is vital. With the guidance of facilitator and the help of technology, the engagement of students may increase, and the possibility to make students active in their learning will also be noticed. For instance, Hadjerclaimed that:

m-learning can be used, but it should not be the focus as we are still in need of physical interaction that is based on the creativity and the personal critical thinking, as relying on the existing thoughts can inhibit individuals' thinking (Hadjer).

Thus, there is a strong acceptance that these collaborative activities enhance student engagement in EFL.Within technology, teachers can be facilitators of the learning process where students can also assist in the facilitation process by taking active part from the other end. This interaction adds value to the teaching and learning process. This informs that interaction is crucial to student engagement, and technology can play a main role in the process. In this way, it can be understood that learning and teaching have two facets according to my research. Firstly, technology helps in pedagogy while in a true sense, everything behind the technology is pedagogy. One of the comments students made is that m-learning may help in developing a pedagogy that can match the old and new teaching methods. One student stated that:

\section{An opportunity to blend or reconcile the old and the new ways of teaching and learning (Mustafa).}

Furthermore, by implementing m-learning activities, students acknowledge that discussions, class interaction resulted in high student engagement.These positive attitudes, therefore, assisted in my understanding of the effectiveness of $\mathrm{m}$ learning in EFL. The designed m-learning activities gave students an understanding of the importance of its use in their learning. It also helps develop knowledge of academic skills that will be significant in their future career as teachers.

This study may attract the attention of the English language teachers to the importance of applying the m-learning activities to add methods in teaching English language. This study may improve student engagement that leads to student achievements to learn English. The findings of this study will reflect possible benefits to student engagement 
resulting from using m-learning, and fromsuggesting ways m-learning can play a part in ELT (English Language Teaching) in Algeria, and possibly to other similar settings.

The greater availability of technological tools promises to offer more effective teaching approaches, but the success of it needs to be assessed in specific situations. Thus, institutions that apply the suggested approach derived from the results of this study will be able to train teacher students better. Administrators will be guided on what should be emphasised by students to increase student engagement in ELT. For the researcher (s), this study may help them reveal critical areas in the educational process that many academics were not able to explore. Thus, new theories on learning English may be suggested. These discussions are useful to establish pedagogical frameworks, which uses some understandings of enhancing EFL student engagement through the use of m-learning.

This study is bound to some limitations. First, the Wi-Fi was the biggest limitation that impeded the effective use of those apps. Second, the generalisability of these results is subject to certain limitations, my study focused only onfirstyear EFL Algerian students at Teacher Training Institute, so the results should be generalised to all language learners very carefully. Third, the small size of the participants, which was limited to 10 students. It can be recommended that further research is necessary to look at the feasibility and acceptability among funders such as government bodies in order to raise awareness of the role of m-learning in the Algerian HE.

\section{References}

Baxter, P. and Jack, S. (2008) Qualitative case study methodology: Study design and implementation for novice researchers. (Report). The Qualitative Report, 13(4), pp.544-559. Retrieved from https://go.gale.com/ps/i.do?id=GALE\%7CA191646999\&v=2.1\&u=nene_uk\&it=r\&p=AONE\&sw=w

Benmoussat, S. \&Benmoussat, N. D. (2018) The teach-to-the-test approach: Doing harm to the lifelongeducational paradigm of Algerian EFL learners, English Language, Literature \& Culture, 3 (1), 1-6. Retrieved from http://article.ellcjournal.org/pdf/10.11648.j.ellc.20180301.11.pdf

Braun, V. \& Clarke, V. (2006) Using thematic analysis in psychology. Qualitative Research in Psychology, 3(2), 77101. Retrieved from https://www.tandfonline.com/doi/pdf/10.1191/1478088706qp063oa?needAccess=true

Bruner, J. \& Watson, R. (1983) Child's talk: Learning to use language. Oxford: New York: Oxford University Press.

Creswell, J. (2014) Research Design: Qualitative, Quantitative, and Mixed Methods Approaches. $4^{\text {th }}$ Ed, International Student ed.

Dewitt, D., Alias, N. \& Siraj, S. (2015) Collaborative learning: interactive debates using Padlet in a higher education institution. Department of Curriculum and Instructional Technology, 1-9.Retrieved from https://pdfs.semanticscholar.org/519d/de364697b2163f9f6537722e44a6d5401865.pdf?_ga=2.140388403.1668 057960.1586023664-766841996.1586023664

Dillon, J.T. (2007) Effects of questions in education and other enterprise, in I. Westbury and G. Milburn (eds.) Rethinking schooling: Twenty-five years of the Journal of Curriculum Studies, London, New York: Routledge.

Dyment, J. E. \& O'Connell, T. S. (2011) Assessing the quality of reflection in student journals: A review of the research. Teaching in Higher Education, 16, 81-97. Retrieved from https://www.tandfonline.com/doi/pdf/10.1080/13562517.2010.507308?needAccess=true

Fuchs, B. (2014) The Writing is on the Wall: Using Padlet for Whole-Class Engagement. LOEX Quarterly, 40(4), pp. 7-9. Retrieved from https://uknowledge.uky.edu/cgi/viewcontent.cgi?article=1241\&context=libraries_facpub

Gergen, K. (2015) An invitation to social construction, $3^{\text {rd }}$ ed. London: Sage Publications.

Ghomari, S. H. (2015) Bridging the Communicative Competence Gap of the English Language in the Workplace Through an ICT-ESP Based Approach of Teaching in Algeria. Procedia - Social and Behavioral Sciences 199, pp. 756-762. Retrieved from

https://reader.elsevier.com/reader/sd/pii/S1877042815046273?token=FD1B65ACABC1B8FF1F9BA7B9E07B 480DE07F08A54CEDEA4442D8D3B61468F2D760D1152ECF465477401ED0528910F54B

Graham, K. (2015) TechMatters: getting into Kahoot! (s): exploring a game-based learning system to enhance student learning. LOEX Quarterly, 42(3), 4. Retrieved from https://commons.emich.edu/cgi/viewcontent.cgi?article=1272\&context=loexquarterly

Hatton, N. \& Smith, D. (1995) Reflection in teacher education - Towards definition and implementation. Teaching and Teacher Education 11(1), 32-49. Retrieved from https://reader.elsevier.com/reader/sd/pii/0742051X9400012U?token=B42913E9239DE1017C9E50F3A29DB2 91226DB9B8F4B1DC73B36A38915BBB556E3AFD4EC1072981BFADCB67CA7495CFD5

Hunsu, N. J., Adesope, O. and Bayly, D. J. (2016) A meta-analysis of the effects of audience response systems (clickerbased technologies) on cognition and affect. Computers \& Education, 92, pp. 102-119. Retrieved from 
https://reader.elsevier.com/reader/sd/pii/S0360131515300853?token=51F65D00A052FB72A30D1869AEDE9 58DCA43B9280EC649AE64413CA8410082B9994E78D6181CE35CDDAAC38D70D9A5CD

Jones, R. C. (2008) The "Why" of Class Participation: A Question Worth Asking. College Teaching, 56(1), 59-63. Retrieved from https://www.tandfonline.com/doi/pdf/10.3200/CTCH.56.1.59-64?needAccess=true

Kuh, G., Kinzie, J., Buckley, J., Bridges, B. \& Hayek, J. (2007) Piecing Together the Student Success Puzzle: Research, Propositions, and Recommendations. ASHE Higher Education Report, 32(5), 1-182. Retrieved from https://onlinelibrary-wiley-com.ezproxy.northampton.ac.uk/doi/epdf/10.1002/aehe.3205

Phelps, R. (2005) The potential of reflective journals in studying complexity 'in action'. Complicity. An International Journal of Complexity and Education, 2, 37-54. Retrieved from https://pdfs.semanticscholar.org/4c15/6f17483476809615f8c54c02a122f3ce7bc0.pdf

Pritchard, A. \&Woollard, J. (2010) Psychology for the Classroom: Constructivism and Social Learning, 122. Florence: Taylor and Francis.

Sera, L., and Wheeler, E. (2017) Game on: The gamification of the pharmacy classroom. Currents in Pharmacy Teaching and Learning, 9(1), pp. 155-159. Retrieved from https://reader.elsevier.com/reader/sd/pii/S1877129715301866?token=A5DF5DA35AFB4797358E5B4D9C287 9936D20C4D13F3034A0CB5E759AF8165A983E26721501E1BCC4E5BDE0B142F3370D

Winer, M. \& Ray, K. (1994) Collaboration Handbook, Creating, Sustaining and Enjoying the Journey. St Paul, MN: Wilder Foundation.

Xerri, M., Radford, J. \& Shacklock, K. (2018) Student engagement in academic activities: A social support perspective. Higher Education, 75(4), 589-605. Retrieved from

https://link.springer.com/content/pdf/10.1007/s10734-017-0162-9.pdf 